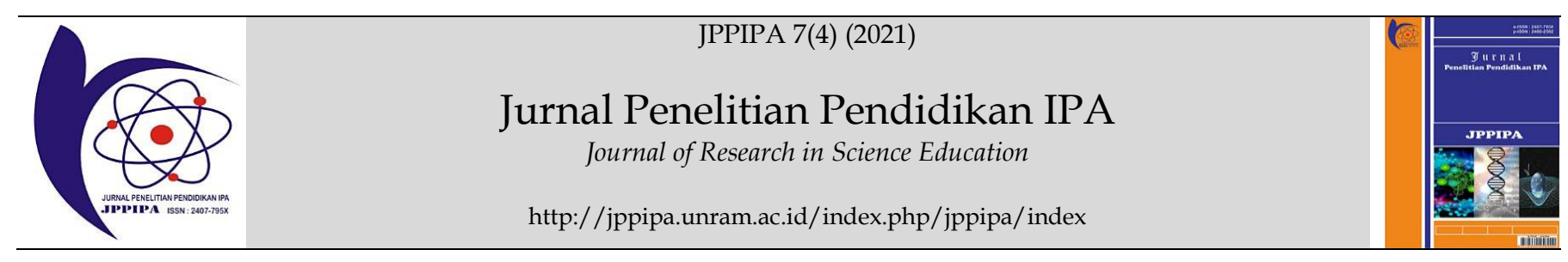

\title{
The Development of Learning Tools in Project-Based Learning Oriented Creative Thinking
}

\author{
Nursamsu $^{1 *}$, Rachmatsyah ${ }^{1}$ \\ ${ }^{1}$ Departemen of Biology Education, Universitas Samudra, Langsa, Indonesia
}

DOI: $\underline{10.29303 / \text { ippipa.v7i4.853 }}$

\section{Article Info}

Received: July 29th, 2021

Revised: September 15th, 2021

Accepted: October 10th, 2021

\begin{abstract}
Learning tools are a set of learning equipment arranged to support the learning process. The project-based learning model is considered as one of the excellent learning models in developing various basic skills within students, such as decision-making skills, creative thinking skills, and problem-solving skills. The design of research used a type validation study, which aims to prove learning theories. The results of the lesson plan validation test as the development of biology learning tools include a very feasible category with a score of $86.75 \%$. The result of students' worksheet validation is in a very good category with a value of $89.0 \%$. The validation of teaching materials was categorized very well, with a value of $88.2 \%$, and the validation of the evaluation sheet is in the very good category with a value of $88.53 \%$. Furthermore, the practicality test to four teachers got responses about $78.13 \%$, which indicates that the assessment is in good criteria. It can be concluded that the learning kits are feasible to be implemented in the learning activity process.
\end{abstract}

Keywords. Development; PjBL; Creative Thinking

Citation: Nursamsu, N., \& Rachmatsyah, R. (2021). The Development of Learning Tools in Project-Based Learning Oriented Creative Thinking. Jurnal Penelitian Pendidikan IPA, 7(4), 676-681. doi:https://doi.org/10.29303/ippipa.v7i4.853

\section{Introduction}

Learning tools are the most important things in teaching and learning activities. The process of learning activities cannot be separated from learning tools. There are various kinds of learning tools used for the learning process. As stated by Borich (2007), learning tools can be in the form of learning materials, tools, media, instructions, and guidelines used in the learning process. From this description, it can be stated that learning tools are a collection of media or facilities used by teachers and students in the learning process or a series of learning tools that a teacher must prepare when dealing with a learning activity. In this paper, the author limits the learning tools to (a) Lesson plan, (b) Student Worksheet, (3) Teaching Materials, and (4) Evaluation Sheet. Learning tools are used to support the learning process, which contains a learning plan and includes actionable steps to achieve student competence. Therefore, an educator must be able to design excellent learning tools with appropriate methods in accordance with the character of the material presented (Prasetyo et al., 2015).

Since planning is the systematic process of deciding what and how the students should learn (Amir and Taufiq, 2010), the preparation of learning tools will help the teacher to deliver learning materials effectively, the learning tools are a set of learning equipment compiled to support the teaching and learning process, such as lesson plans, learning material, and student's worksheets (Schunk, 2012).

Designing learning tools is important knowledge for students of the Faculty of Teacher Training and Education, where lecture materials are related to the activities of compiling learning tools. Thus, the use of Project-Based Learning (PjBL) is very appropriate to be implemented in learning activities as an assignment for students in making learning tools.

Project-based learning can stimulate students to be able to develop creativity through problem-solving 
activities and creating projects. Abidin (2014) states that the project-based learning model is considered as one of the effective learning models in developing various basic skills within students, such as decision-making skills, creative thinking skills, and problem-solving skills. The same opinion was expressed by Hwang et al. (2007) that creativity is an ability that can be grown and developed through a problem-solving process.

A creative person will be able to solve the new problem their face in their daily life. Moreover, the creative thinker will be more sensitive to the problem (Aktamis et al., 2008). Project-Based Learning (PjBL) is one of the meaningful learning models that actively engages students, facilitates students to create the solution actively, and makes the learning fun (Abdullah \& Ridwan, 2014). Creativity is one of the parts of higher-order thinking skills (Andi, 2013). Furthermore, creative thinking also playing an important role in affect students' activity and their development. Creative thinking is an interesting field to study, although it is still hard to implement (Yuwono, 2010).

The achievement of creative and reasoning skills of Indonesian students nowadays is categorized as very low. The scientific research reveals it is only $6 \%$ of students could achieve high order thinking ability. The result means that creative thinking skills are still hard to implement, but it doesn't rule out the possibility of getting used to them (Suhadi, 2007). That's why Project Based Learning (PjBL) is appropriate to implement in learning evaluation courses, which can lead students to complete the duty into project, which indirectly increases their creative thinking. In this duty, the students will do a survey in school and starting their project of making a new learning tool based on the problem they found in school. This project aims to make students able to create their own syllabus, lesson plan, learning media, learning materials, and questions related to the topic. This project will produce a valuable product for the students as a candidate teacher.

\section{Method}

This study uses a design research method where the presentation of materials using a project-based learning model. The research design used was the type of validation study which aims to prove learning theories (Gravemeijer and Cobb, 2006). The research aims to develop a product in learning tools that aim to stimulate students' creative thinking skills. The development model used in this study is the Dick and Carey model. The products developed are learning tools consisting of lesson plans, teaching materials, student worksheets, and evaluation sheets.
The data collection was carried out by observing and giving questionnaires. Instruments for learning products in this research are the validation sheets for learning tools related to the feasibility of lesson plans, teaching materials, student worksheets, and evaluation sheets. Meanwhile, the practicality test was obtained through a questionnaire to the Biology teacher.

Data analyses are carried out to produce qualify, valid, practical, and effective learning tools or products. So, to meet these criteria, an analysis of validity, practicality, and effectiveness was carried out. The practical data is analyzed through a Research design, and the method should be clearly defined, teacher response questionnaire to learning tools that use the Project Based Learning (PjBL) Model.

\section{Result and Discussion}

\section{Results}

The results of this study consist of two parts, namely, the results of product development and the results of product trials. The process of implementing development research consists of several stages, namely (1) the preliminary study and information collection stage; (2) the planning and design stage; and (3) the stage of compiling and developing a draft. At the preliminary stage, information collection consists of several stages, namely classroom observation, literature study, and a research framework. The next stage consists of planning and designing, containing content structure analysis, concept map analysis related to the material, and analysis of learning objectives. The process of implementing research activities related to product development and product trial results can be explained below.

\section{Development of Product}

The feasibility of the developed learning media is assessed through lesson plan validation, student worksheet validation, teaching material validation and evaluation sheet validation. The lesson plan validation sheet refers to Permendikbud Number 22 of 2016 (Kemendikbud, 2016). The components that become the core of lesson plan validation are: (1) Completeness of lesson plan identity; (2) The suitability of the material presented with Core Competencies (KI), Basic Competencies (KD) and Competency Achievement Indicators (IPK); (3) Learning Objectives; (4) Time allocation: efficient and effective; (5) Learning materials; (6) learning activities; (7) learning media, tools, and resources; (8) The suitability of the assessment guidelines on the rubric of the student activity observation sheet. The results of the lesson plan validation test can be seen in Figure 1 below. 


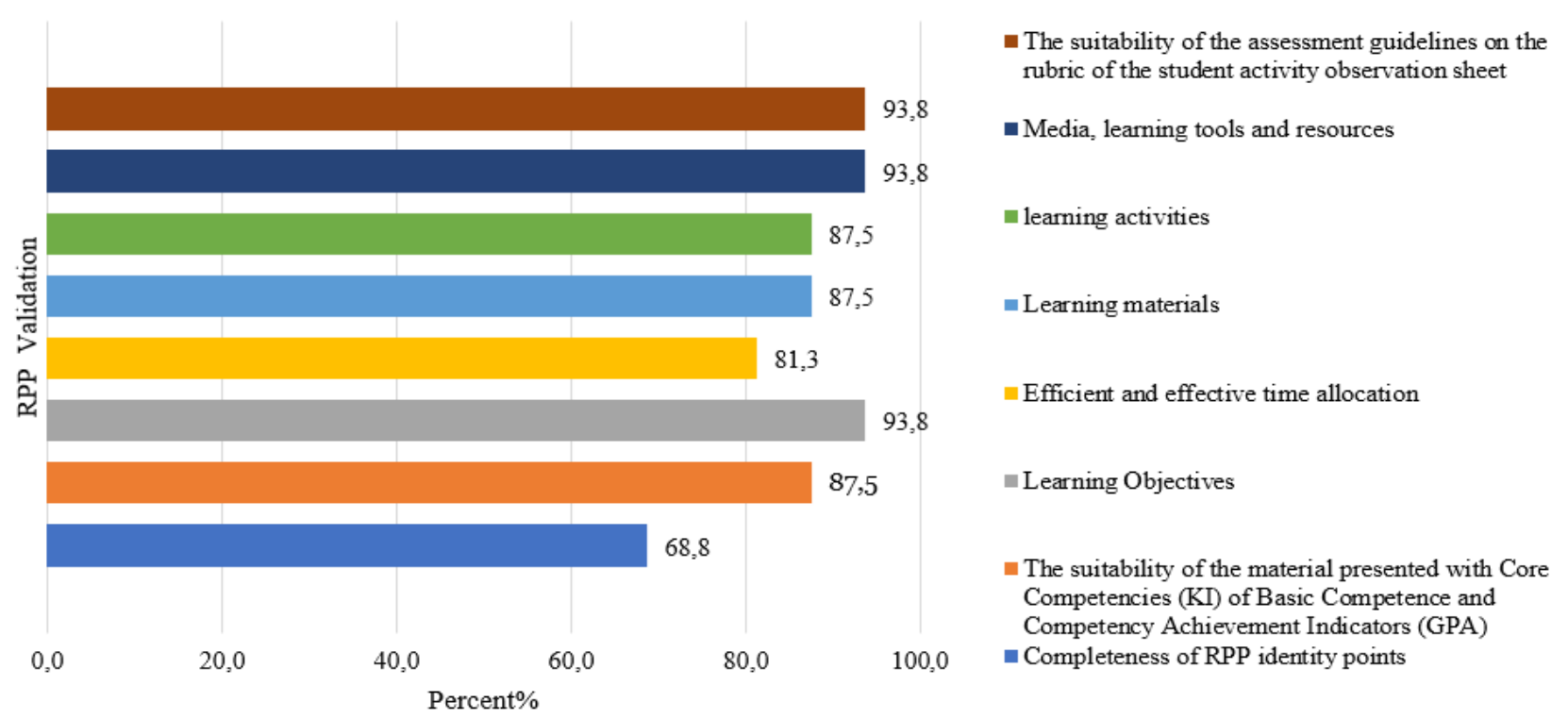

Figure 1. Lesson Plan Validation

Figure 1 explains that the lesson plan validation test results as the development of biology learning tools are included in the very feasible category with an average score of $86.75 \%$. After the lesson plan validation test results are obtained, the student worksheet validation test is carried out, referring to the 2008 Ministry of National Education and the National Education Standards Agency (BNSP 2014). The components that include validation of student worksheets are (1) content feasibility, (2) the feasibility of presentation, (3) language eligibility, and (4) the feasibility of graphics.

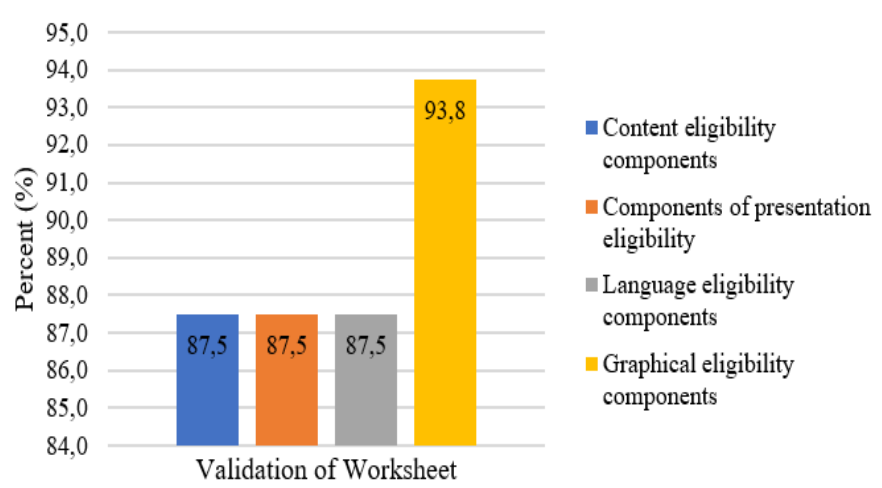

Figure 2. Worksheet Validation Test

The results of the analysis of student worksheets in Figure 2 shows that the validation of the worksheets is in a very good category. It can be seen from the value of the model in each aspect assessed. The average value of validator 1 is 4 , with an amount of $89.0 \%$, which shows that the validation of the worksheet is in very good criteria.

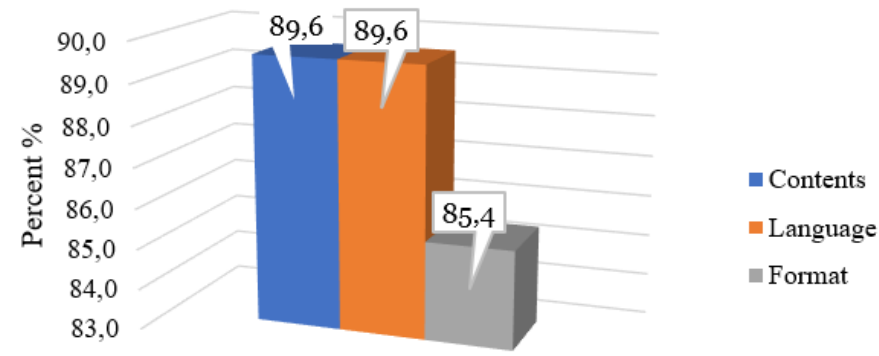

Learning Material Validation

Figure 3. Learning Material Validation Test

Figure 3 shows that the validation of teaching materials is in the very good category. It can be seen from the value of the model in each aspect that is assessed. Furthermore, the average score of validators 1 is 4 with an average value of $88.2 \%$ with means the teaching material is in very good criteria.

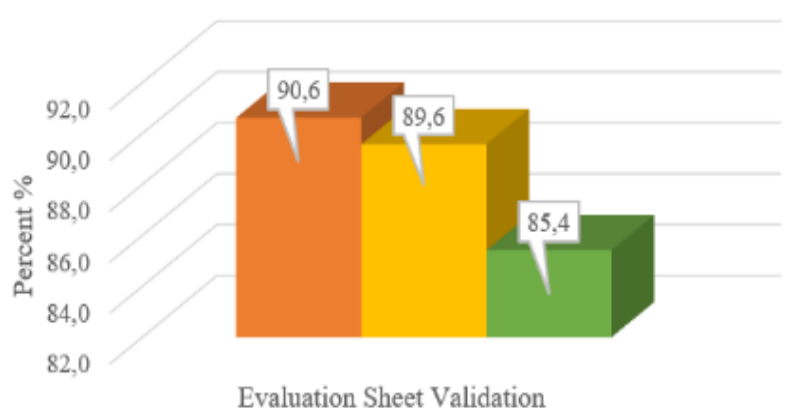

=Question Language $=$ Problem Construction $=$ Question Material

Figure 4. Worksheet validation

The validation results of the evaluation sheet in the table above show that the evaluation sheet is in the very good category with a score of $88.53 \%$. Then, the 
practicality data of the product obtained through the questionnaire to the teachers are described below.

\section{Practicality Test}

The biology learning tools developed in this study are considered practical if the practitioners state that the biology learning tools with the Project-Based Learning (PjBL) model are easy to apply in the learning process. In short, the implementation of learning tools is included in the "good" category

Based on the results of field trials, data on the practicality of learning tools based on the Project-Based
Learning (PjBL) model were obtained through teacher response questionnaires. The teachers who filled out the response questionnaire were two teachers who had used learning tools during the field trials. The results of the teacher's assessment (in percentage) can be seen in Figure 5 below

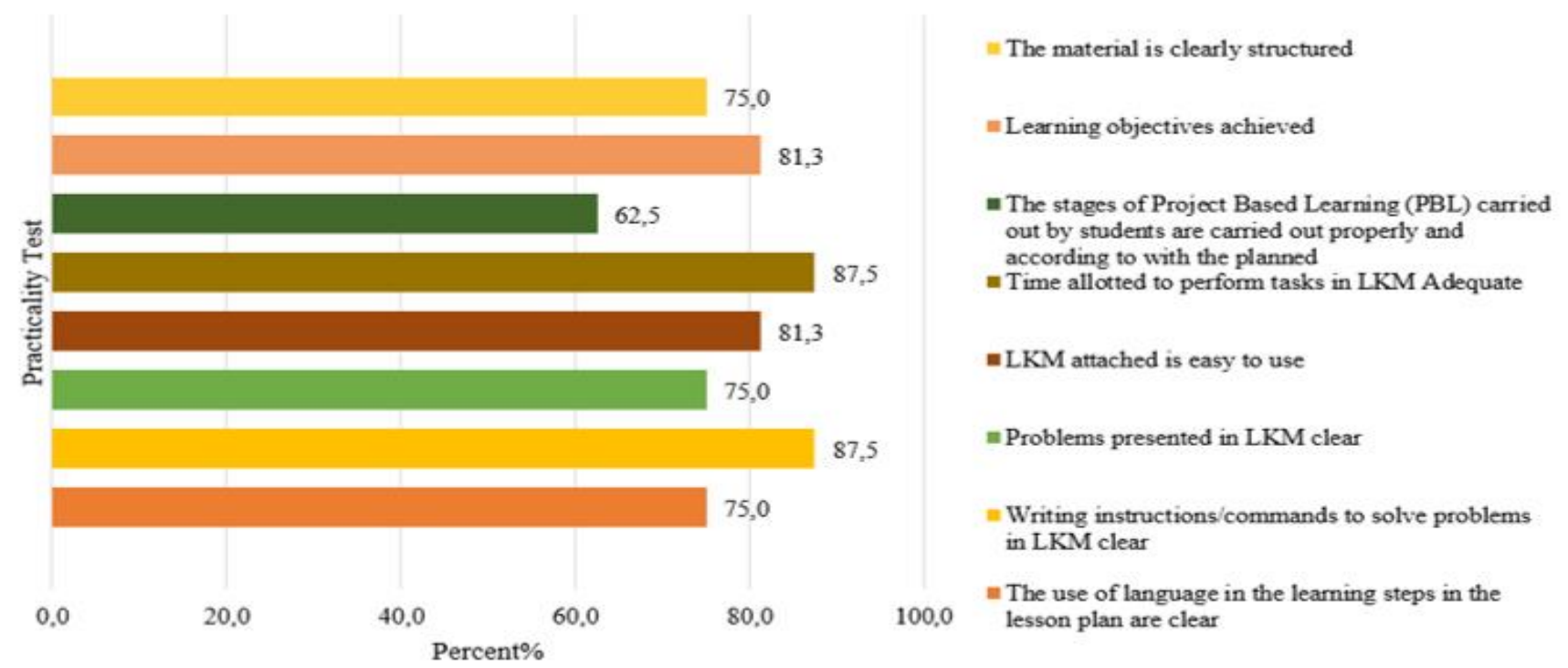

Figure 5. The result of practicality test by Biology teachers

Based on the responses of biology subject teachers to the questionnaire on the product that has been developed, it shows that the average total response of the four teachers is $78.13 \%$ which indicates that the assessment is in good criteria.

\section{Discussion}

This research consists of several aspects that become the focus of research, namely learning tools and product trials. The results of the development of learning tools consisting of four aspects, namely (1) lesson plan validation test, (2) students worksheet validation test, (3) validation test of teaching materials, (4) evaluation sheet validation test, was declared very good, which means the learning product could be continued with the practicality test. The teacher conducted the results of the product practicality test in the field of biology studies by filling out a response questionnaire to the resulting product. It is concluded that the product developed was in a good category. The results of this study are in accordance with the research of Mukra and Nasution (2016), which explains that Project Based Learning is higher than Problem Based Learning. The Project-Based Learning model has more advantages: increasing motivation, improving problemsolving skills, improving literature study skills, increasing collaboration, and improving resource management skills.

Creativity is needed to generate new ideas in order to solve problems, make improvements, increase effectiveness, and add value (Isa and Jamil, 2012). The same thing was conveyed by Plucker (Kaufman et al., 2008) that creativity makes a person or group able to produce new and useful products. Learning by utilizing PjBL-based interactive multimedia can help create meaningful learning for students (Habib et al., 2020).

In learning using learning tools with an ethnoscience approach, students are actively involved in learning so that they have a better understanding than students who study conventionally. Students who are active in learning activities will have better understanding and learning outcomes than students who only listen to the teacher's explanations and are passive during the learning activities (Shahali \& Halim, 2010). As stated by Karamustafaoğlu (2011) that science process skills are thinking abilities that are used to obtain information. The PjBL is a method in which 
students engage in intellectually challenging tasks that encourage the acquisition of knowledge and skills used in solving complex problems (Movahedzadeh et al., 2012).

Bagheri et al. (2013) said that one of the advantages of project-based learning is that students determine their own project goals and choose projects according to their own interests. The evaluation stage is the LKS that has been designed based on the development steps, and then a thorough evaluation needs to be carried out to ensure that the LKS is in accordance with the ADDIE model steps. According to Aldoobie (2015), the evaluation of the ADDIE model aims to evaluate every step that has been achieved by using instructional design and materials to meet student needs.

Applications of real-world theory, exploratory opportunities and practical design skills, and peer learning are considered by students as the most valuable aspect of project experience (Chen et al., 2015). Project-based learning (PJBL) provides opportunities for students to build this quality and learn more deeply the traditional academic content and understand how it applies to the real world (Dias \& Brantley-Dias, 2017).

Sumantri et al. (2015) said that Project Based Learning $(\mathrm{PjBL})$ is the application in education is to enhance the creative abilities of learners, collaboration capabilities, and self-direction. Yalcin (2009) that project-based learning can affect attitudes, motivation to learn physics, and thinking skills development. Through project-based learning (PjBL) activities, students have high motivation to develop their competencies because student project assignments are real projects raised from problems that develop in the community (Jalinus et al., 2017).

\section{Conclusion}

Based on the results of the study, it can be concluded that at the stage of developing learning tools using the Project-Based Learning (PjBL) model, the perception/assessment results between the four validators are generally categorized as very good, while the results of the practicality test can be concluded that the learning tools are feasible to be implemented in learning activities.

\section{Acknowledgments}

The research team would like to thank LPPM and PM of Samudra University, who have provided DIPA funds through superior basic research grants so that the research runs well.

\section{References}

Abdullah \& Ridwan, S. (2014). Pembelajaran saintifik untuk kurikulum 2013. Jakarta: Bumi Aksara. [Indonesian]

Abidin, Y. (2014). Desain sistem pembelajaran dalam konteks Kurikulum 2013. Bandung: Refika Aditama. [Indonesian]

Aktamis, H. \& Omer E. (2008). The Effect of scientific process skills education on students' scientific creativity, science attitudes and cademic achievements. Asia- Pacific Forum on Science Learning and Teaching, 9(1). Retrieved from: https://eric.ed.gov/?id=EJ832103.

Aldoobie, N. (2015). ADDIE Model. American International Journal of Contemporary Research, 5(6):68-72.

Amir, M. \& Taufiq. (2010). Inovasi Pendidikan melalui Problem Based Learning Bagaimana Pendidik Memberdayakan pemelajar di Era Pengetahuan. Jakarta: Prenada Media Group.

Andi, P. (2013). Panduan Kreatif Membuat Bahan Ajar Inovatif. Jogjakarta: Diva Press. [Indonesian]

Bagheri, M., Zah, W., Ali, W., Abdullah, M. C., Abdullah, B., Daud, S., Malaysia, P., \& Malaysia. (2013). Effects of Project-based Learning Strategy on Self-directed Learning Skills of Educational Technology Students. Contemporary Educational Technology, 4, 15-29. https://doi.org/10.30935/cedtech/6089.

Borg, W. R. \& Gall, M. D. (2007). Educational research $8^{\text {th }}$ edition. New York: Longman.

Chen, P., Hernandes, A.,\& Dong, J. (2015). Impact of Collaborative Project-Based Learning on SelfEfficacy of urban Minority Students in Engineering. Journal of Urban Learning Teaching and Research. 11:26-39.

Dias, M., \& Brantley-Dias, L. (2017). Setting the Standard for Project Based Learning: A Proven Approach to Rigorous Classroom Instruction. Interdisciplinary Journal of Problem-Based Learning, 11. https://doi.org/10.7771/1541-5015.1721

Gravemeijer \& Cobb. (2006). Design Research from a Learning Perspective, dalam Educational Design Research. New York: Routledge.

Habib, A., Astra I.M., \& Utomo, E. (2020). Pemanfaatan Multimedia Interaktif: Pengembangan Media Pembelajaran Berbasis PjBL (Project Based Learning). Prosiding Seminar dan Diskusi Nasional Pendidikan Dasar "Transformasi Pendidikan Menyogsong SDM di Era Society 5.0. Retrieved from:

http://journal.unj.ac.id/unj/index.php/psdpd/ article/view/17796 [Indonesian] 
Hwang W. Y., Nian-Shing C., Jian-Jie D., \& Yi- Lun Y. (2007). Multiple representation skills and creativity effects on mathematical problem solving using a multimedia whiteboard system. Educational Technology \& Society, 10 (2). 191-212. Retrieved

from: https://eric.ed.gov/?id=EJ814045

Isa, A. \& Jamil A. (2012). How to measure students' creativity. Journal of The Asian Conference on the Social Sciences Official Conference Proceedings, 2186- 2303.

Jalinus, N., Arwizet, K, Nabawi, R. A. and Ambiyar. (2017). Improve Learning Outcomes of Students Through Implementation of The Collaborative Project-Based Learning Model in Thermodynamics. Proceeding the 1st International Conference on Education Innovation, 1(1): 559-564.

Karamustafaoglu, S. (2011). Improving the science process skill abylity of science student teachers using i diagram. Eurasian J. Phys. Chem. Educ, $3(1), \quad 26-\quad 38 . \quad$ doi: https:// doi.org/10.51724/ijpce.v3i1.99

Kaufman, J.C., Jonathan C. P., \& John B. (2008). Essentials of creativity assessment. John Wiley \& Sons, Inc., Hoboken, New Jersey.

Kemendikbud. (2016). Permendikbud Nomor 22 Tahun 2016 Tentang Standar Proses Pendidikan Dan Menengah. Jakarta: Kemendikbud. [Indonesian]

Mardapi, D. (2008). Teknik penyusunan instrumen tes dan non tes. Yogyakarta: Mitra Cendikia Press. [Indonesian]

Movahedzadeh, F., Patwell, R., Rieker, J. E., \& Gonzalez, T. (2012). Project-Based Learning to Promote Effective Learning in Biotechnology Courses. Education Research International, 2012, 536024. https://doi.org/10.1155/2012/536024.

Mukra, R., \& Nasution, M.Y. (2016). Perbedaan Hasil Belajar Siswa Menggunakan Model Project Based Learning dengan Problem Based Learning pada Materi Pencemaran dan Pelestarian Lingkungan Hidup. Jurnal Pelita Pendidikan, 4(2). 122-127. doi: https:// doi.org/10.24114/jpp.v4i2.4053 [Indonesian]

Prasetyo, Z. K., Senam, Wilujeng, I., Anjarsari, P., Wibowo, W. S., Putri, R. A., Katriani, L., Ariyati, D., Wardani, Y. R., Khoirunnisa, O. A., Firdausi, I. R. A., \& Hardina, M. (2013). Pengembangan Perangkat Pembelajaran Sains Terpadu Untuk Meningkatkan KOgnitif, Keterampilan Proses, Kreativitas Serta Menerapkan Konsep ilmiah Siswa SMP. In laporan kegiatan Program Pengabdian kepada Masyarakat. Retrieved from: http://lppm.uny.ac.id/sites/lppm.uny.ac.id/file s/ZuhdanKunPrasetyo_PPM_UNG.pdf

[Indonesian]
Schunk, D.H. (2012). Learning Theories: An Educational Perspectives, 6th Edition. New York: Pearson Education Inc.

Shahali, E. H. M., \& Halim, L. (2010). Development and validation of a test of integrated science process skills. Procedia - Social and Behavioral Sciences, 9, 142-146. https://doi.org/10.1016/j.sbspro.2010.12.127.

Suhadi. (2007). Petunjuk Perangkat Pembelajaran. Surakarta: Universitas Muhammadiyah. [Indonesian]

Sumantri, S.S., Wuryandini., \& Sudarmin. (2015). Project Based Learning Model Development on Buffer Solution Materials with Soft Skill Entrepreneur Oriented. The International Journal Of Engineering And Science (IJES).4(6). 5-10.

Yalcin. A. (2009) The Effect of Project Based Learning on Science Undergraduates' Learning of Electricity, Attitude towards Physics and Scientific Process Skills. International Online Journal of Educational Sciences. 1 (1): 81-105. 